\title{
Dimensions of spatial inequalities in the Information Age: the case of Hungary
}

Dimensões da desigualdade espacial na Era da Informação: o caso da Hungria Les dimensions de l'inegalité spatiale dans l'Age de l' Information : le cas de l'Hongrie

Dimensiones de la desigualdad espaciales en la era de la información: el caso de Hungría

Ákos Jakobi, Brigitta Zsom and Zsófia Vida

\section{(2) OpenEdition}

\section{Journals}

Electronic version

URL: http://journals.openedition.org/espacoeconomia/4797

DOI: 10.4000/espacoeconomia.4797

ISSN: 2317-7837

\section{Publisher}

Núcleo de Pesquisa Espaço \& Economia

\section{Electronic reference}

Ákos Jakobi, Brigitta Zsom and Zsófia Vida, « Dimensions of spatial inequalities in the Information Age: the case of Hungary », Espaço e Economia [Online], 13 | 2018, Online since 16 December 2018, connection on 20 April 2019. URL : http://journals.openedition.org/espacoeconomia/4797 ; DOI : 10.4000/espacoeconomia.4797

This text was automatically generated on 20 April 2019.

(C) NUPEE 


\section{Dimensions of spatial inequalities in the Information Age: the case of Hungary}

Dimensões da desigualdade espacial na Era da Informação: o caso da Hungria Les dimensions de l'inegalité spatiale dans l'Age de l' Information : le cas de l'Hongrie

Dimensiones de la desigualdad espaciales en la era de la información: el caso de Hungría

Ákos Jakobi, Brigitta Zsom and Zsófia Vida

\section{Introduction. Conceptual background of inequality theories in the information age}

1 Alongside of traditional factors of inequalities some new ones seem to emerge nowadays, which have thorough effects on geographical disparities. In connection with the trendy phrase of information society growing practical experiences confirm that processes affecting regional differences are reflecting certain new characteristics. For example, by the evolution of the new innovations or novel information and communication technologies (ICTs) a transformation process has begun, which has changed our opinion on the advantages and disadvantages of geographical location, distance, size or other geographical factors. In information inequalities besides economic and social factors thus an increasing role is believed to be played by geography as well. By the recognition of the growing importance of the topic, modern geography has certainly the task to discover and evaluate the main characteristics of changes induced by the information age. Actually, there is an increasing demand on clarifying what reasons are in the background of disparities. The explanation of the function of geography in information inequalities by the clarification of accessibility disparities, e-government inequalities, network 
disparities and cyberspace differences could serve the better understanding of recent days' altering processes.

Information society as a distinctly new socioeconomic concept, motivation factor and value system burst upon the scene, though not without preliminaries, in the last few decades; it is a consequence of the social evolution caused by accelerated technological development. The commercial opening of the internet at the beginning of the '90s brought really important changes into the previously almost closed world of the Web. The new innovation was spreading at an unprecedented rate, and has required a completely new way of thinking, which proved to be an extremely useful instrument and also created new opportunities. Although computers and mobile phones were in use much earlier and information and knowledge have always been important, the substantial change was due to all these elements being associated with the main production factors (besides labour force and capital), thus gaining much more importance than simple tools.

3 In truth the term "information society" has been used by researchers since the 1960s (Umesao, 1963; Porat, 1977) and has appeared from utopian to matter-of-fact scientific approaches in many contexts. It has had the highest occurrence among the keywords of publications in the last couple of decades (Masuda, 1988; Fichman, 1992; Castells, 1998; Trujillo, 2001; van Dijk, 2005). The research of ICT-based inequalities despite the novelty of this term is already not unknown in circles of international researchers. Basic works of Castells $(1996,1997,1998)$, Norris (2001) or van Dijk (2005) formulated many concepts on inequalities of the information society. Also regional aspects of this topic became widely analyzed (Goddard et al. 1985; Odendaal, 2003), however it has still a lot of questions to be answered, especially in relation with cyberspace inequalities and those effects on traditional geographical features. Joining to this, actually, it seems to be a re-emerging question, whether ICT-based inequalities are typically new ones, or they are just reshaping existing differences.

Digital divide or the digital gaps are the expressions of the researchers of information society on describing how specific the inequalities are in this environment. In the background of ICT-based differences there are (also) general social distinctions, namely income, education, gender or age differences of the population (Servon, 2002), which are basically traditional inequality factors even in the information age. We should note that digital divide cumulatively foster existing social inequalities, therefore in that sense the factors of information inequalities may be considered also as traditional, or at least transforming ones, although ICT still have in majority new type of differentiating effects. All in all, if we go into details, we might discover that there are traditional, altering and new inequality motives within the topic of information age disparities, too.

Models, which try to explain and quantify inequalities of information accessibility and information usage, evaluate the factors of early and late phases of technological development differently. Professionals explain the altering role of the influencing effects of factors related to inequalities of information society typically by the assistance of diffusion models (e.g. Hüsing et. al, 2001; OECD, 2001), primarily starting from that inequalities are basically determined by the adaptation level of ICT. Social and spatial diffusion in time is characterized by a logistic curve, which shows a time-lagged shape depending on the development level of the analyzed target group (Figure 1.). As a result of later adaptation certain social groups (for example peripheral regions) are becoming relatively lagged behind, which can be realized in social and spatial inequalities. In phases 
of the adaptation process different types of inequalities can be discovered. In early adaptation phase, when only few applies ICT, differences can be seen in accessibility, in the phase of take-off the differences are present between users and non-users, while in the phase of saturation differences in quality can be emphasised. As a result, ICT-based inequalities can more or less be measured by the society's adaptation level.

Figure 1. Diffusion model of ICT innovations in the group of early and late adopters (own construction based upon Hüsing et al. 2001)

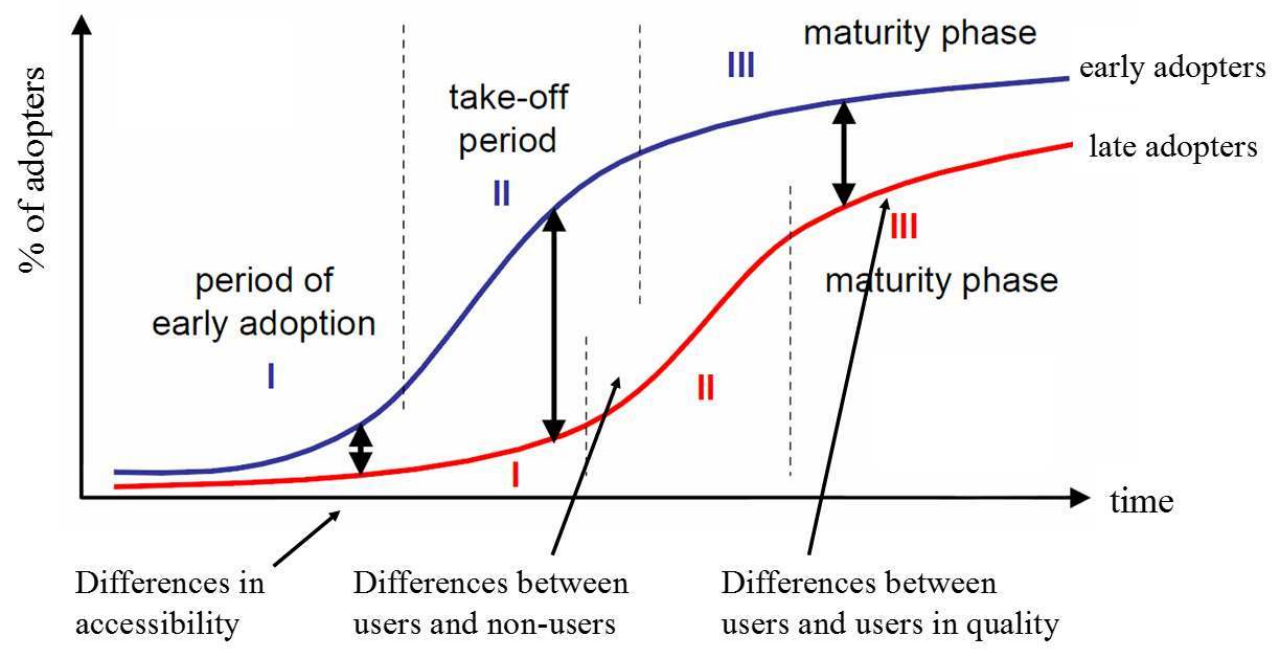

The theory that ICT-related inequalities have different contents depending on the phase of ICT adaptation were further detailed for example in social (Galácz and Molnár, 2003) or in methodological contexts (Dolničar, 2008). Additionally, the above mentioned model is suitable to explain the changing nature of the ICT-related geographical inequalities as well, if regional adaptation level of ICT innovations were taken into account. In this modified model the first order geographical inequalities appear in connection with differences of infrastructure in the traditional and "physically existing" space, which can also be named as the external space of the information society and economy. This phase of regional inequalities is basically characterised by differences of accessibility to information tools and channels. Typically the unequally built-up environment of information and communication infrastructure is among the most important measurable factors. The second phase of ICT-related geographical inequalities has fewer relations with external space; rather it is dependant on "internal" inequalities those are disparities of social origin. In this phase accessibility is still an important factor of inequalities, however, with decreasing significance, while usage inequalities are gaining notable importance. Our concept is to measure here the penetration rate of ICT usage (or any similar or connecting indicators) both in regional context. In the third phase the main accessibility disparities are disappearing or dissolving and the usage differences remain as inequality motives, however, this time only the quality differences are counting. Technically this phase is the most difficult to measure, since there are only few regional datasets about the quality of ICT usage, however, some experiments already successfully managed to collect data on this topic.

7 Consequently, in the following we aim to present the composite character of Hungarian information society differences in a regional context. First, the accessibility dimension of information age disparities is detailed by the application of typical statistical indicators. 
Secondly, we attempt to draw the picture of e-government disparities, a new layer of information inequalities, to represent differences between users and non-users. Next, we present examples on network-based inequalities as an experimental study on the importance of connectivity in the information economy. And finally, we aim to give examples on novel forms of cyberspace inequalities reflecting regional differences of how people are using and taking advantage of information age possibilities.

\section{Inequalities from the point of view of traditional ICT indicators}

8 Since there are infrastructural bounds of the chance of getting information, and the pattern of the built-up infrastructure is not equalized spatially, the inequalities should have geographical consequences as well. Telecommunication channels, cable networks of information transference are representing the specific at the same time significantly important material fundamentals of the communication infrastructure that is forming the technical system of conditions of the information society. Actually the most important "public utility" of the information society, the cable system of information transmission plays the main role in the infrastructure-centred version of the external space of the information economy and society.

9 Concerning regional differences, the level of built up infrastructure as well as distance from access points of networks is assumed to be more unfavourable in geographically peripheral places. Accessibility is though a central category of the geography of information society. It worsens the chance of peripheries since the deployment of technical systems as the "soul" of network society is defined by market regularities of economy, hence infrastructure differentiates society and space also on its own. Centreperiphery relations live further in urban-rural differences, additionally inequalities are defined along city-hierarchy as a result of that nodes of information and communication networks are to be found basically in urban spaces, and the density of connecting services and activities is also the highest at these locations.

10 To test this assumption, empirical statistical experiments should be carried out by collecting regionally detailed data on information accessibility. As a starting point we analysed the existing methodology to find the best measures of regional inequalities. Although there are many internationally well known attempts to measure ICT-based regional inequalities or at least the level of information society development (see e.g. ITU, 2012), the formulated methods can not be implemented one in one for all kind of regional analysis. The major problem is that international indices take into account variables, which are possible to be collected on country levels, but are rarely available for smaller regional units. The lack of territorially detailed data (basically due to the lack of small scale data collection) resulted that a large number of indicators should be left out from analysis, or alternative solutions should be found. Also due to the novelty of factors, regionalists often struggle with data problems, and can therefore make only general models and measurement experiments of their own; no wide-spread consensual measure or methodology has yet evolved. On regional differences in the development of the information society there are some notable early research experiments in Hungary, which also reflects the new character of this topic (Nagy, 2002). 
Since the term of accessibility is a complex one, no simple indicator can be found to characterise it; therefore multi-variable methods have had to be elaborated. To quantify disparities of information accessibility already many experiments were carried out (Corrocher and Ordanini, 2002), mostly dealing with complex sets of indicators, featuring infrastructural and social causes of information accessibility. Typical complex analyses apply indicators that were formerly also important in affecting inequality processes, and on the other hand new indicators that have recently become indispensable. For example, the calculations and the methodology of World Times and International Data Corporation for the year of 2001 used 23 different indicators in its composite index. Among the indicators we find those representing the phases of invention, innovation, diffusion and adaptation of the innovation chain. An other widely spread methodology is represented by the International Telecommunication Union's Digital Access Index (DAI), which applies the direct indicators of accessible infrastructure and costs, as well as the indirect indicators of social adaptation. Accordingly, based upon international examples, our calculation - represented in the followings - tried to find the best selection of variables in relation with regional scale information accessibility.

In order to represent the ICT-infrastructure based regional disparities within Hungary, microregional (LAU-1) level data were collected for 175 spatial units. The dataset was formulated by ICT-infrastructure related indicators, which represent the accessibility of information. Data were provided by the Hungarian Central Statistical office and by surveys of GKIeNET (an ICT research company in Hungary). The dataset referred to the year 2010 depending on common data availability. The final dataset covered the following indicators:

- Number of personal computers in households per 1000 people (Source: GKIeNET)

14 - Number of mobile phone subscriptions per 1000 people (Source: GKIeNET)

15 - Number of telephone main lines and ISDN lines per 1000 people (Source: HCSO)

16 - Number of cable TV subscriptions per 1000 people (Source: HCSO)

17 - Number of internet subscriptions per 1000 people (Source: GKIeNET)

The complex index of information accessibility was created by the application of the well known simple Bennett methodology (Bennett 1954). Data were represented as percent of the maximum value and averaged by small regions with the following simple formula (1):

$$
I_{j}=\frac{\sum_{i=1}^{M}\left(\frac{x_{i j}}{x_{i \max }} \cdot 100\right)}{M}
$$

where $I_{j}$ is the complex index of information accessibility in region $j, X_{i j}$ is the value of indicator $i$ in region $j, X_{\text {imax }}$ is the maximum value of indicator $i$ in the dataset, and $M$ is the number of indicators. Values of the estimation range from 0 (the worst) to 100 (the best).

Figure 2. represents unweighted results of Hungary's regional structure of information accessibility. The map shows the definite difference observed by city-hierarchy, which is reflected by the above average attendance of urban areas. Meanwhile another significant 
feature is the lagging of the eastern part of the country. Regional differences between eastern and western parts of the country, particularly the lagging of the eastern GreatPlains regions is remarkable. At the same time maximum values of the index are located mostly in the agglomeration of Budapest, in metropolitan regions (Györ, Debrecen, Szeged), as well as in some adjacent zones in Central-Transdanubia and NorthwestHungary, whilst the minimum values of the index can be connected mostly to small regions of East- and Northeast-Hungary.

Figure 2. Complex information accessibility index of microregions in Hungary, 2010 (own calculation of the authors)

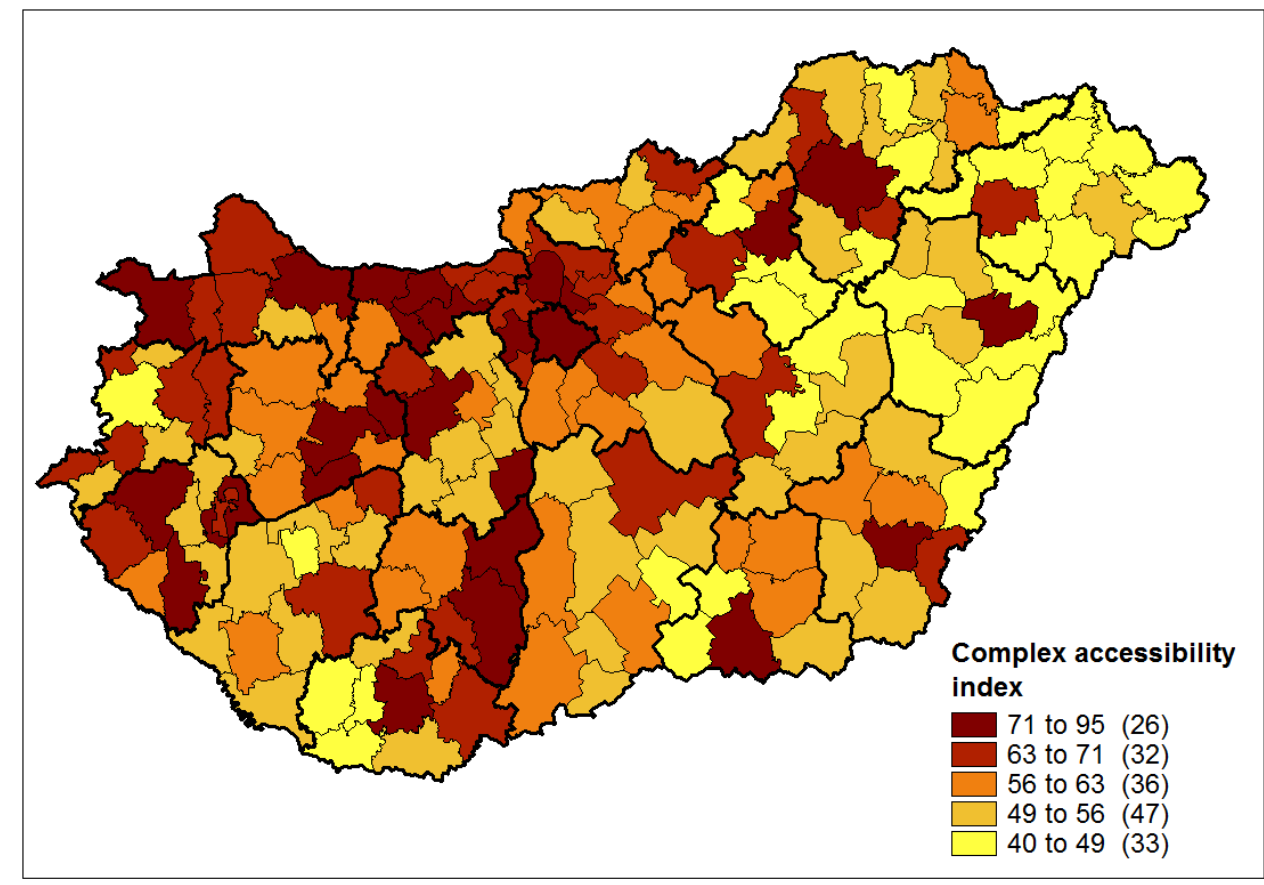

The result map mirrors the unequal chance of getting information in different regions of Hungary, although there are some other geographical factors of accessibility, which can possibly be taken also into account. Besides statistically measurable data we should be aware that physical geography also determines the possibility of accessing telecommunication channels. There are bounds and barriers of "overall information accessibility" due to constraints of geographical environment, in which for example the relief (mobile phone access in mountainous areas) or the cost of building infrastructure to remote, peripheral villages could also play some role (but basically on micro scales, and with minor influences). This confirms again that geography still matters in the information world.

\section{The e-government dimension of inequalities}

Inequalities are not just questions of accessibility to information infrastructure; we should recognize the people behind the ICT as users, who are included to or left out from the information channels. The inclusiveness of the people has many facets, of them an important one is connected to the development of e-government. 

impact on everyday life including also the public sphere. This is because ICTs offer new possibilities for the government to provide services for and among citizens, business actors, non-governmental and governmental institutions. We may consider the evolution of e-government to one of the biggest technology-based service innovations of the public sphere. With regard to public-administration management and in relation to information society policies one of the main challenges of the information age is to create an inclusive e-government and to overcome the digital divide, which manifests itself in social, economic and regional inequalities. be defined among wide conceptual borders. On the one hand ICT policies are responsible to develop information accessibility to people, but another useful tool (among many others) is the evolution of e-government services, and to provide wide range of possibilities to manage public topics. By the wide diffusion of e-government technologies (online public services, intelligent websites, e-friendly administration etc.) we may expect the overall increase of information age skills and decrease of digital lagging also in territorial contexts.

As a consequence of last decades' unequal spatial development processes, naturally also differences in certain motives of the e-government is possible to detect. In the following we aim to introduce some examples of the e-government related spatial inequalities in Hungary from the aspect of supply and demand side.

As for the supply side inequalities of e-government, the unequal spatial pattern of high or low level e-government development stages of localities could draw an interesting picture. GKIeNET, an ICT research company in Hungary, has published for many years regionally desaggregated data in relation to e-government. Data were collected from a municipal IT survey, in which local governments had to rank their own institution on a scale of 1 to 4 representing different e-government development stages. The survey was conducted in every year from 2002 to 2010 among local governments on the level of settlements. Concerning the applied scale the value of 1 refers to the so-called "information" stage (where users can only search and download information from the governmental websites), 2 refers to "interaction" stage (in this stage interaction is limited, users can download forms), 3 refers to "transaction" stage (for example: users can purchase licences without going in an office, or can make their local tax returns via internet) and 4 refers to "transformation" stage (for example users can vote electronically) (Budai - Tózsa, 2007).

Figure 3. The supply side of e-government: different e-government development stages of microregions in Hungary, 2010 (own construction based on GKIeNET data) 


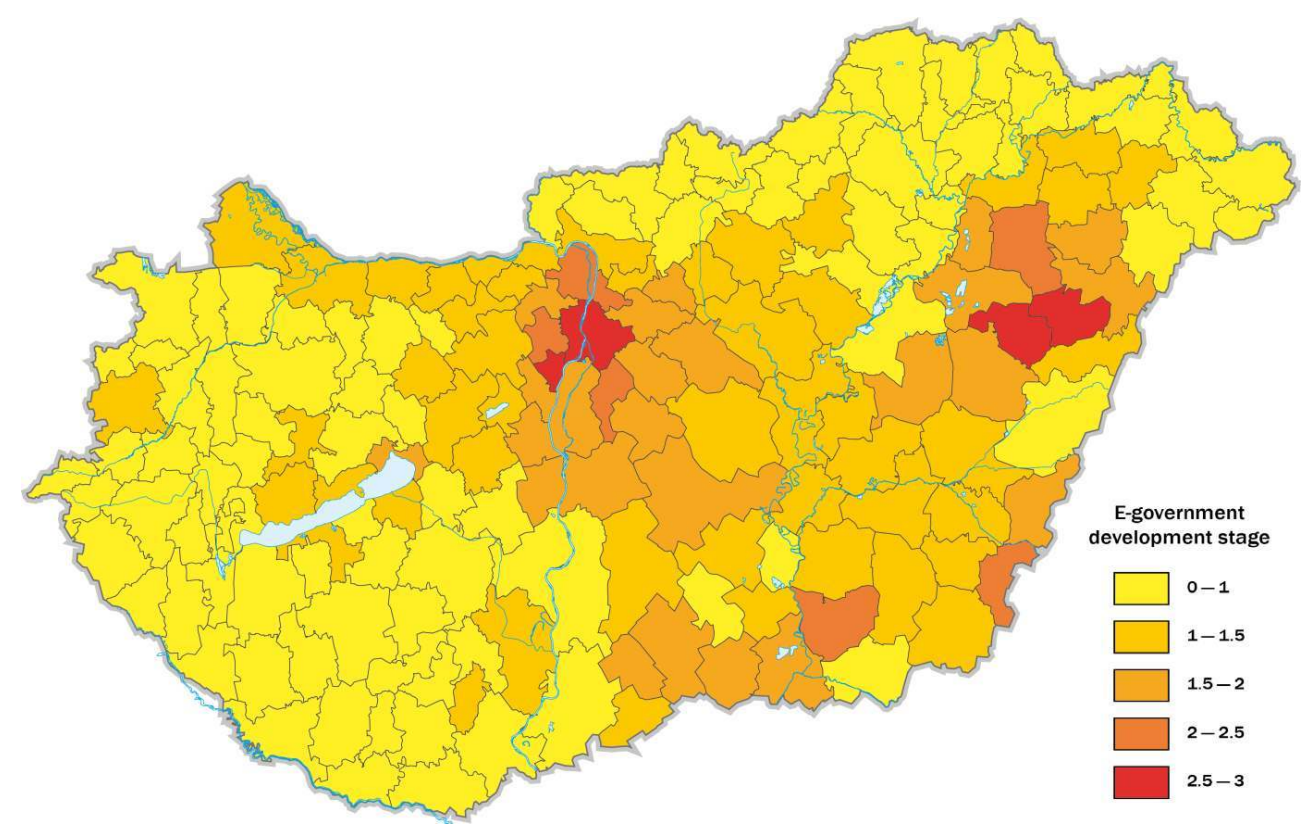

Figure 3. depicts spatial inequalities of e-government development stages of microregions (LAU-1) in Hungary, in 2010. The aggregated mean was calculated from the local level of e-government data. On the map light colors refer to the lowest level of e-government development stages (1) and darker areas represent the highest level (3) of e-government development stages. At the time of the survey we found no settlements (or microregions) in Hungary having a rank of 4 , which meant that the "transformation" stage has not been reached yet in Hungary. The aggregated mean values show that most of the LAU-1 units are in "information" stage, which means that real e-administration has not been realized in many areas yet. The stage of e-government development is somewhat higher in Budapest and in the agglomeration of the capital city and also high in some regional centers (such as Debrecen, Szeged). On the other hand e-government development stage seems to be lower in the North-Eastern and South-Western regions of the country, primarily at peripheral areas.

As a complement of the above mentioned topics, the development level of e-government could be analyzed from the aspect of demand side as well. The Hungarian Statistical Office and Eurostat have conducted a household survey in every year since 2002. Around ten thousand individuals participated in the survey asking questions on ICT usage in households and by individuals (for more details see Eurostat 2013). Among the questions an instructive one was about whether the respondent "has performed any administrative procedures electronically". From the results we may expect that regions with a higher rate of positive response could possibly be on an advanced or at least developed level of egovernment, since locals willing to do more administrative actions electronically. The outcomes on an aggregated level of NUTS-2 regions are presented in Figure 4. 
Figure 4. The demand side of e-government: share of respondents from the 18-64 years old population, who "has performed any administrative procedures electronically", in NUTS-2 regions, Hungary, 2010 and 2014 (own construction based on HCSO data)

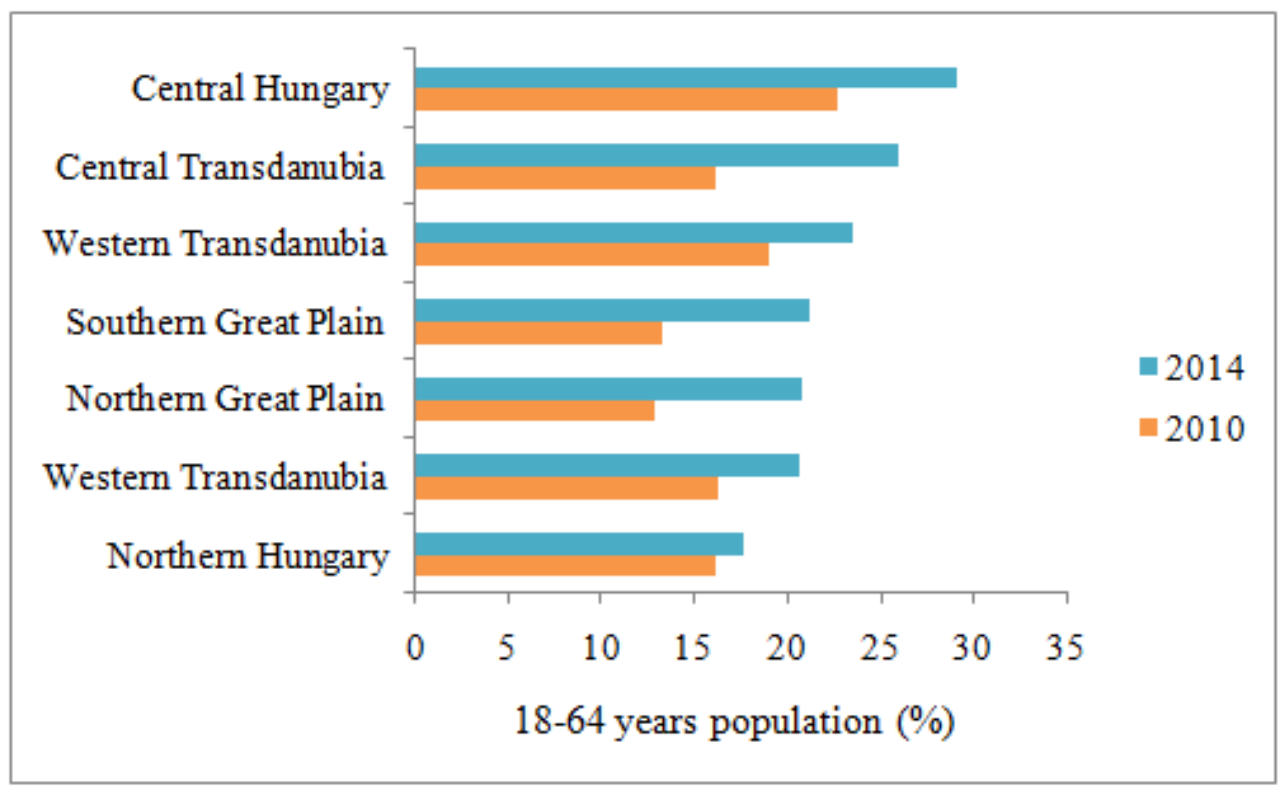

According to the results, the values are reaching from $12 \%$ (Northern Great Plain, 2010) to $29 \%$ (Central Hungary, 2014), showing that around one quarter of the population uses e-government services. In the sense of using ICT for managing an administrative procedure electronically, the region of Central Hungary happened to be the most developed and Northern Hungary as well as Western Transdanubia the less developed regions. It seems the spatial inequality pattern of using e-government services has more or less similar picture than spatial inequalities of e-government development stages.

To represent the connection between ICT usage and e-government needs a good, although indirect example can be derived from the data of the Hungarian Central Statistical Office about the number of people who responded online the official population census questionnaire in 2011. Although most of the people answered the questions of the population census offline (on an official paper form), $18.6 \%$ did it electronically but with an unequal dispersion in space. The results reflected that there was a gap between different types of settlements in the ratio of responding the questionnaire online (Table 1).

Table 1. The share of people who responded online the official population census questionnaire in 2011 as compared to the proportion from the country's total population (\%) (own calculation based on HCSO data)

\begin{tabular}{|c|c|c|}
\hline & $\begin{array}{c}\text { Share of online } \\
\text { respondents (\%) }\end{array}$ & $\begin{array}{c}\text { Proportion from the } \\
\text { country's population (\%) }\end{array}$ \\
\hline Budapest & 29.6 & 17.4 \\
\hline $\begin{array}{c}\text { Country } \\
\text { capitals }\end{array}$ & 23.7 & 20.4 \\
\hline Cities & 15.7 & 31.7 \\
\hline Villages & 10 & 30.5 \\
\hline Country total & 18.6 & 100.0 \\
\hline
\end{tabular}


The thematic map on the level of settlements (LAU-2) also reflects the significant spatial differences of online active population (Figure 5). In settlements represented with darker colors the online response rate was larger than in other areas. In general, we might assume that the more a settlement is developed the higher the rate of online response is. This assumption was tested by a regression model, which came to the result that the 18-39 years old population and the rate of the higher-educated population have the strongest relations with the share of people who responded online the official population census questionnaire.

Figure 5. The share of people who responded online the official population census questionnaire in 2011 , on the level of Hungarian settlements (LAU-2) (own construction based on HCSO data)

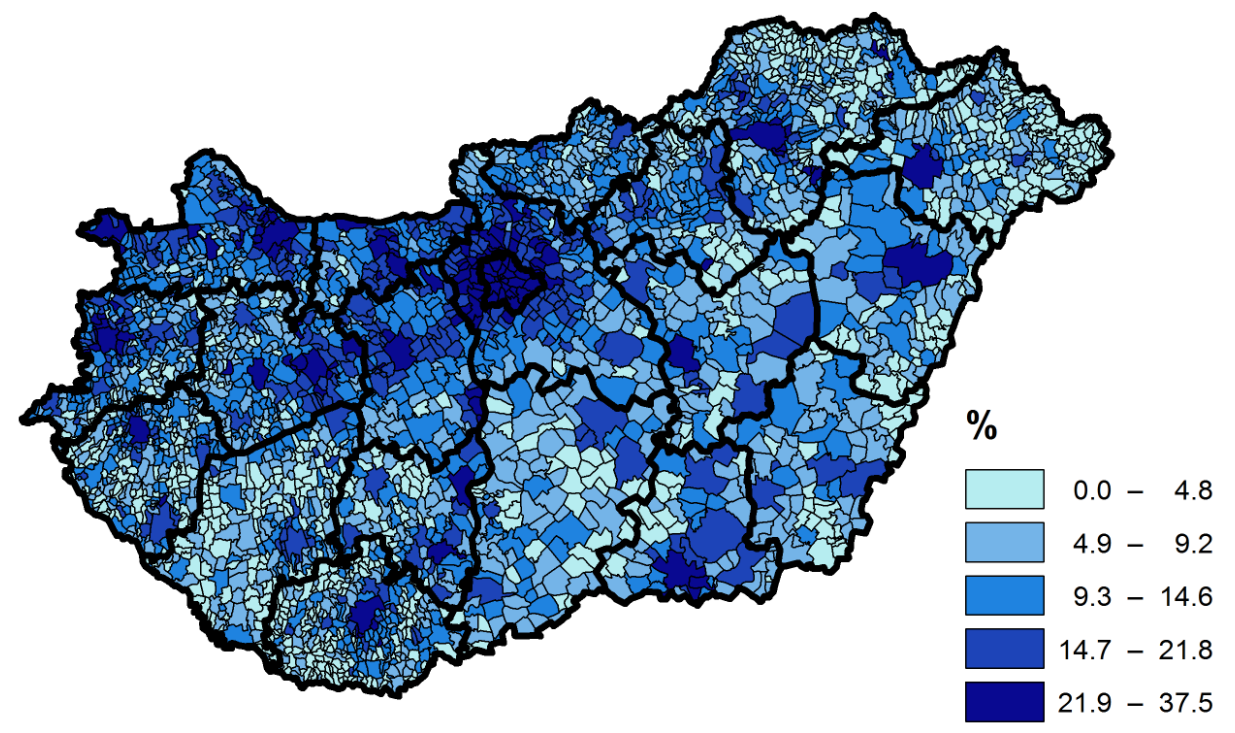

As a conclusion we found that although the e-government dimension has many aspects to view inequalities in the information age, most of the pictures related to this topic definitely distinguish at least two areas: the central (urban) and peripheral (rural) regions.

\section{The network dimension of spatial inequalities}

According to Manuel Castells (1996) one of the most impressive consequences of the information revolution was the evolution of the "network society", a formation where interconnectedness plays the most important role. Although Castells refers to the geography of this era as placeless, where instead of the space of places the space of flows is surmount, there are still possible evidences that the existing network structure of the economy and the society is not completely aspatial. In the following we try to add some thoughts why networks are important factors also in spatial inequalities of the information age.

It seems obvious, that in the age of internet the connectedness to networks is like crucial. But it is not just an infrastructural question of cables and computers: the network formation itself could serve and function as the ether of communication, where actors are 
the nodes and the flow of information between them are the edges. Hence the network point of view can reveal a completely new layer of analysis.

Networks - which are set of nodes and edges - could be described by relation matrices or be visualized by graphs. From these initial outcomes further results could have been derived. The position of a node for example can be expressed in numerical form, by using network indicators like the total number of ties of a node (degree) or centrality, which latter has several measures depending on the research question. Degree centrality, closeness centrality or betweenness centrality (Freeman 1979, Wasserman and Faust 1994) could give new insights to determine important and less important nodes of a network also in a geographical network context. Network centrality indicators could give information not only about the whole network but about each and every node as well. This way we can distinguish nodes having central or rather peripheral position.

Also network density is a good indicator to describe the importance of a local network. The network density is the ratio of the number of the existing relations and the number of the potential relations in the network $\left[\left(\mathrm{N}^{*}(\mathrm{~N}-1)\right) / 2\right.$, where $\mathrm{N}$ is the number of nodes]. The denser a network is the faster the information could spread, therefore places with high network density could be more important than others. Network density is a decisive and relevant topic also when dealing with infrastructural networks (e.g. infocommunication networks). In general it is more expensive to construct and sustain a network with denser structure, but on the other hand we may expect more intensive flowing of things, thus the efficiency of information spreading is better on denser networks.

The next example also deals with network concept, placing companies of the information economy in the focus. Our theory is following the concept that although innovations of ICTs made it possible to allocate any screen-based activities anywhere on Earth (Cairncross 1997), urban areas and agglomerations still have the main power to attract companies to settle. Among many reasons this is also because tacit information flow is more intense in urban areas, namely face-to-face contacts have still a decisive role in company management. The uncodifiable information of face-to-face relations cannot be transferred through the internet, but could be experienced in "urban buzz" (Storper 2003) revaluating therefore the areas of densely connected locations.

In our example we assume that ICT companies located close to each other have greater chance to have fruitful connections than those located far from others. This would have been easily measured by simple density maps of companies, but this time we add also the network dimension to the subject. So additionally we take into account that many companies have not only one but two or more location sites as well, therefore we consider two companies as close if they had their seats or any of their branches closely located. In our next calculations closeness is defined as a distance of less than 2 kilometers. As a result, the seat-and-branch networks of the companies are connecting to each other, hence forming the new network of the interfirm flow of information and knowledge.

Figure 6. Co-location model of seat-and-branch networks of companies 


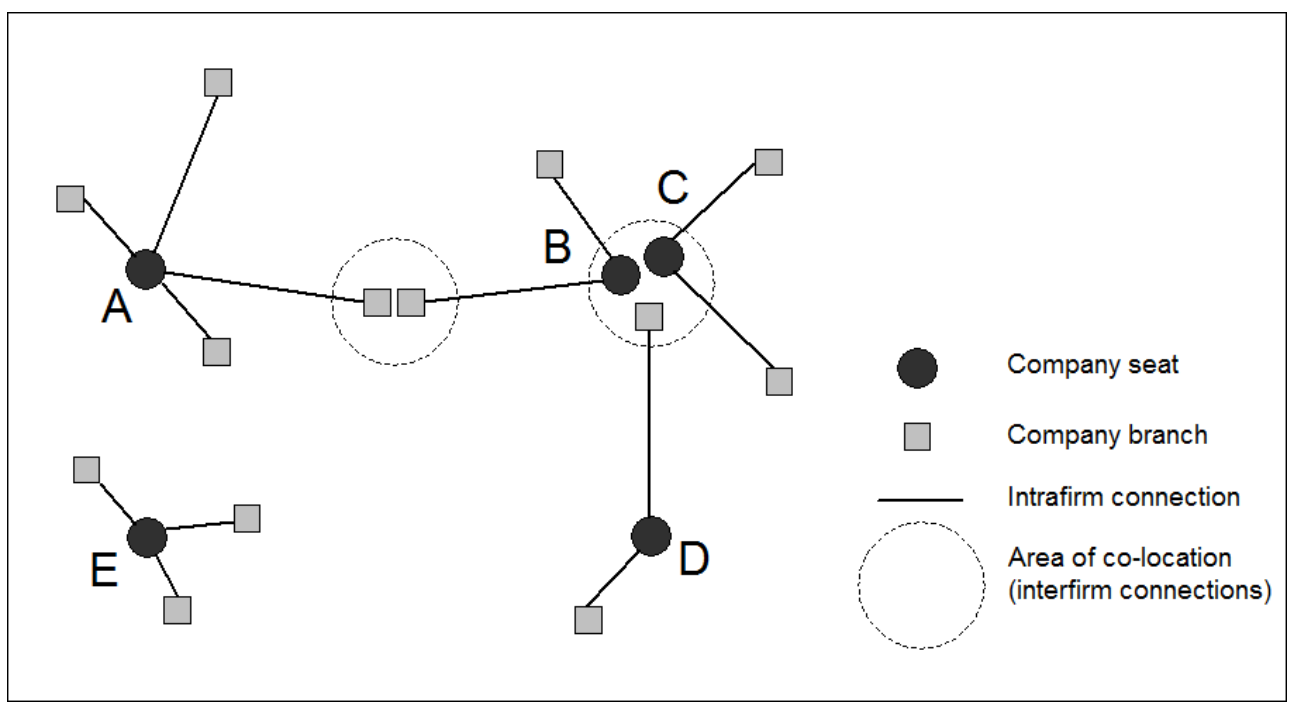

The different forms of company network connections are depicted on Figure 6. We distinguished three basic forms of interfirm connections: co-location of company seats (e.g. between company B and C), co-location of company branches (e.g. between company $\mathrm{A}$ and $\mathrm{B}$ ), co-location between a company's seat and another company's branch (e.g. between company B and company D). Naturally, there exist companies which have no colocated connections with others (e.g. company E). In order to perform the co-location network analysis for ICT companies we used data from the Hungarian Central Statistical Office and ESRI Hungary. The dataset was covering all the companies of the ICT sector in 2013 (selected activities were: computer programming, consultancy and related activities; information service activities), and the geolocated addresses of company seats and branches. By the application of GIS methods we calculated the co-location relations for all ICT companies, therefore we could determine for each microregion the number of firms, which have network connections.

Based on the geographical dispersion of ICT companies in Hungary it was logically expected that most of the firms (including location sites of both seats and branches) are located in populated places. This initial assumption was confirmed by the map depicting the density of ICT companies (Figure 7), showing relatively higher rates in the agglomeration of Budapest and in urban microregions around regional capital cities. 
Figure 7. Number of ICT company seats and branches per $\mathrm{km}^{2}$ (own calculation of the authors)

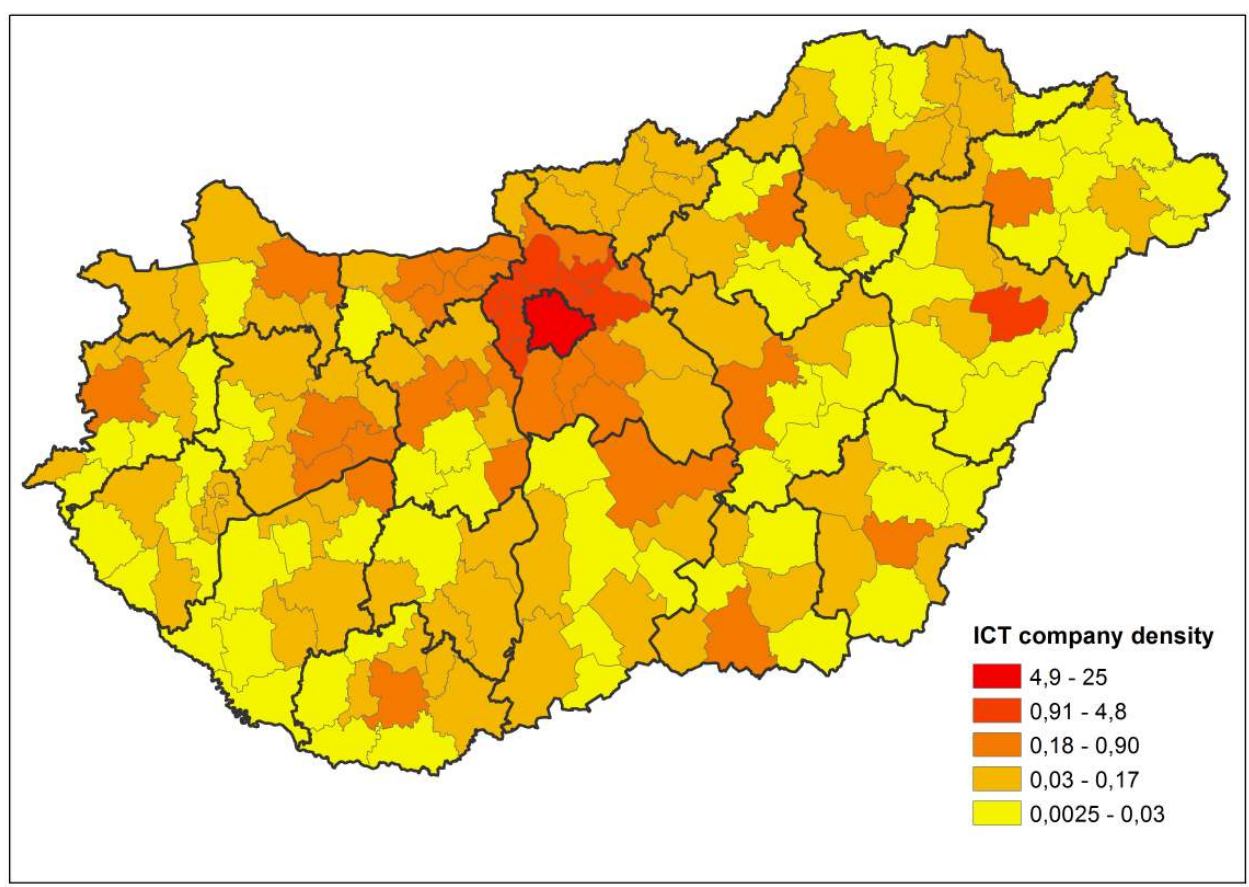

Although according to the absolute number of possible interfirm connections a rather similar map is likely to be drawn, the result map of the relative number of possible network connections reflected though a somewhat different map (Figure 8). Budapest is exceeding from the network space of ICT companies and typically regional centers have good connection values, but some rural areas perform also very good network results. In such cases beside very low number of local ICT companies relatively many has co-located seat-and-branch connections with others. In other words, it is typical that companies with the seat in certain rural microregions have branches in larger cities too (especially in Budapest), and with a chance perhaps could gain from the information and knowledge flow of the co-located partners. 
Figure 8. Number of possible interfirm network connections per 1000 ICT companies (according to the location of company seats) (own calculation of the authors)

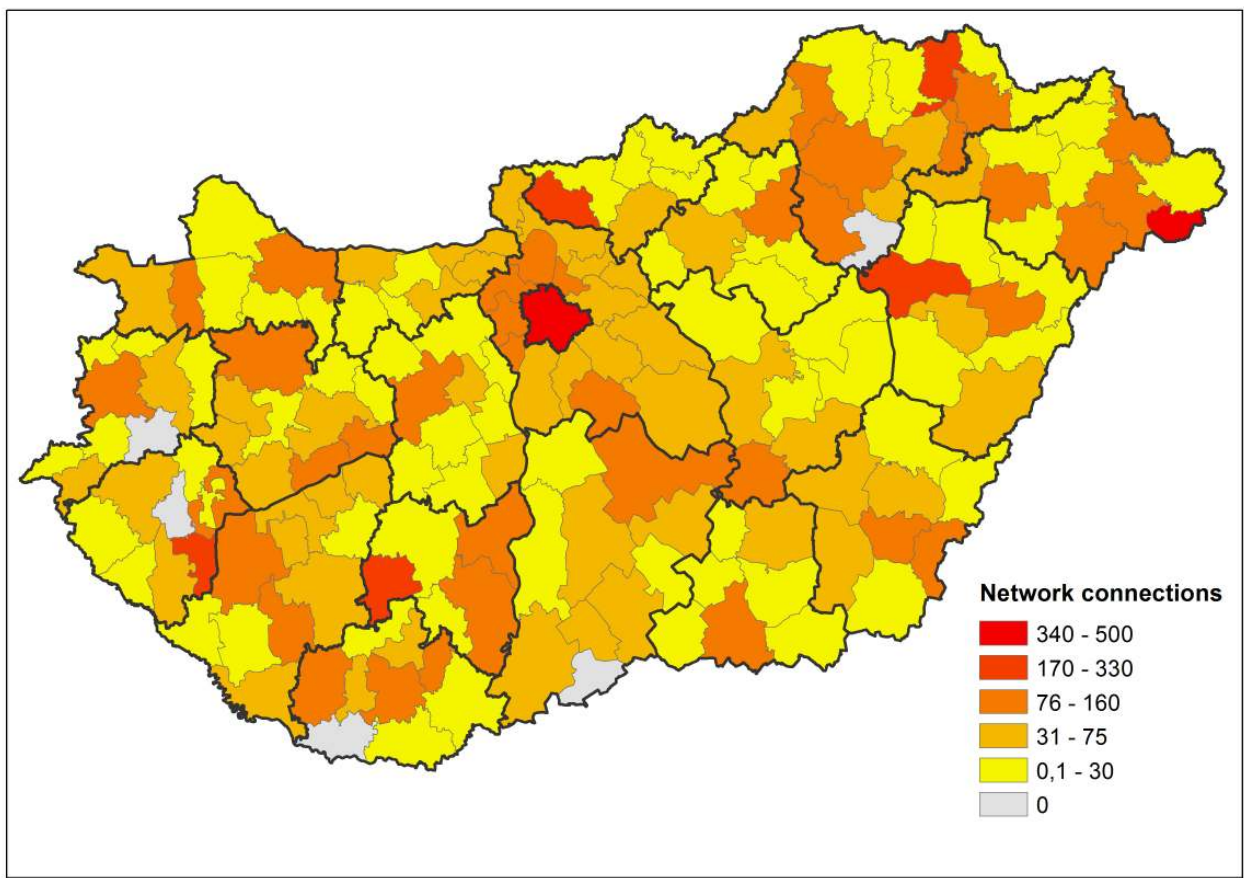

Consequently we found that not only the density of locations could describe the spatial inequalities of the ICT sector, but also the possible network topology of the firms. According to the number of network connections or the results for network centrality measures we consider central the firms having more connections than the others, as well as the regions that are better connected (either in absolute or relative numbers).

\section{New inequality dimensions in cyberspace}

Beside inequalities of ICT indicators a new dimension of disparities is possible to be described by the analysis of digital footprints left in cyberspace. According to our assumption spatial density of digital footprints indirectly reflect the higher or lower intensity of using information devices in a certain area. Due to the fact that smartphones are typically equipped with GPS applications, and because of the increasingly large number of smartphone users, we have the possibility to trace ICT-aware population geographically both in cyberspace and in physical space.

The territorial level of information usage beyond the direct observation of the diffusion of GPS-enabled devices can be experimentally determined or at least approximated by other direct or indirect instruments. The frequency of occurrence and the usage of spatial information can be indicated for example by the diffusion level of geocoded information. There are several websites, where published information are provided with clearly defined location parameters (geocodes), resulting that up-to-now spatially independent information also gained spatial attributes. In an HTML environment geocoded information can be placed in the source of website by geotags. By collecting and mapping geotagged data it becomes possible to determine areas, where users publish spatial information more frequently. 
Figure 9. Density of geotagged Wikipedia articles in Hungary (own calculations based on data of DBpedia)

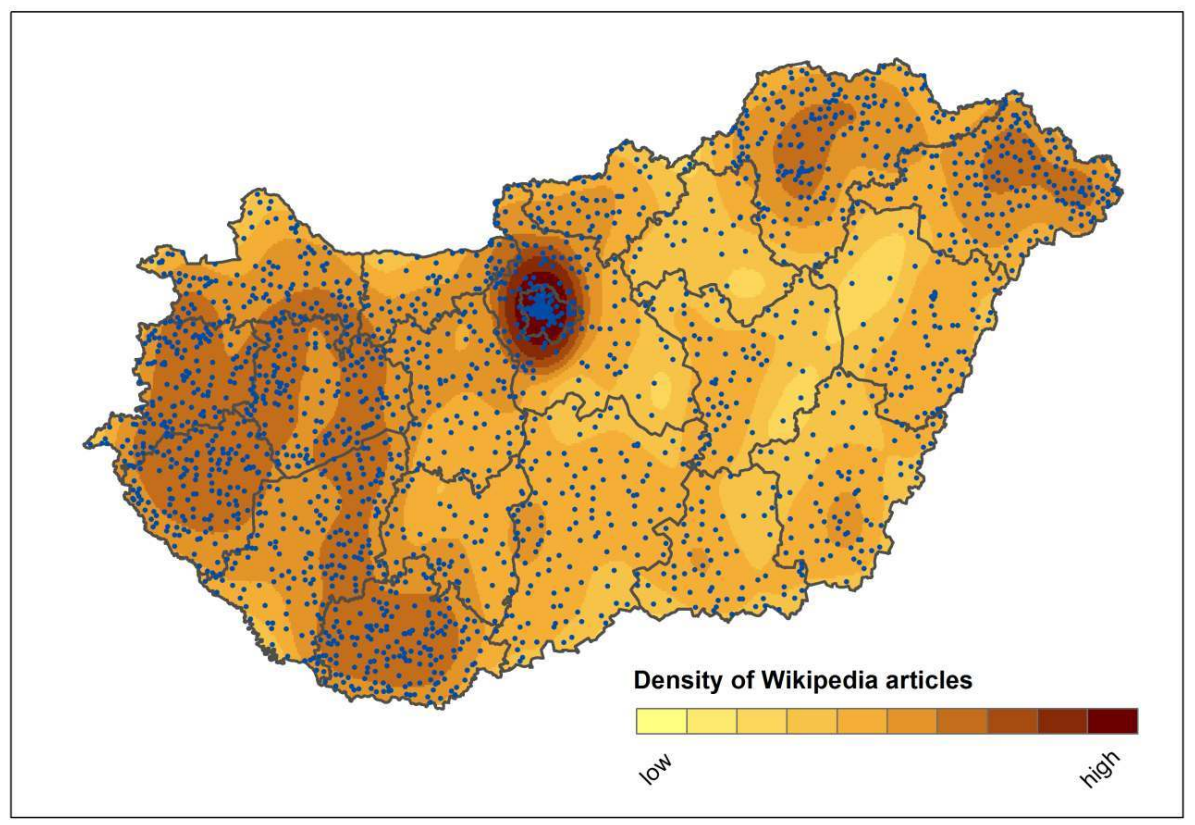

Geotagged spatial information can particularly mirror the inequalities of spatial information usage in case of multi-user-edited open websites (such as Twitter or Wikipedia)(see e.g. Graham and Zook 2011). Figure 9 shows the spatial density of geocoded Wikipedia information that can be located within Hungary. The geographical pattern naturally does not depict the real traffic density, only the relative density of information with spatial content is reflected. The map for the Hungarian results shows again a relative concentration near and inside Budapest but also the wide dispersion of geotags around the country can be noticed. 


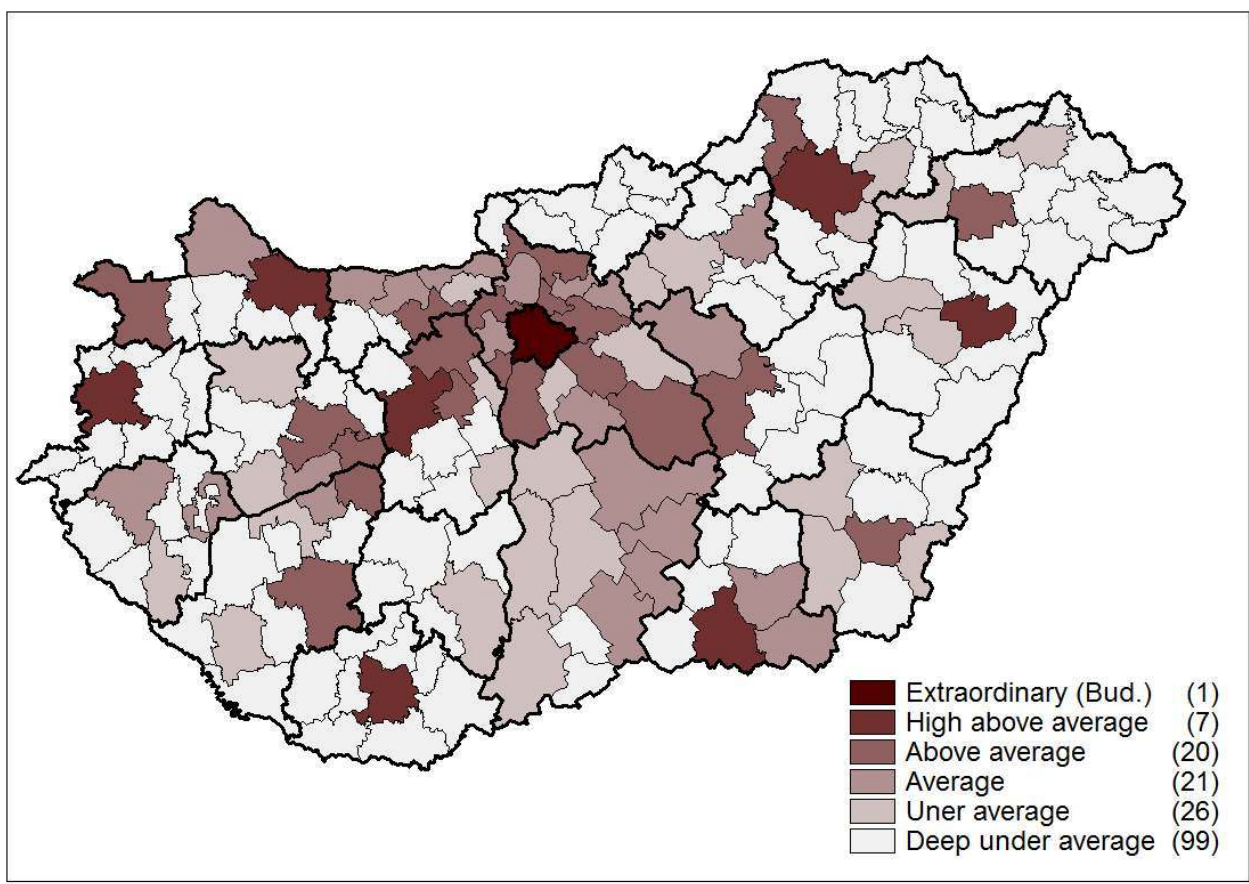

An approximate intensity of digital information usage can be seen on Figure 10, where the aggregated number of geolocated tweets from Twitter is presented on the level of Hungarian microregions. The results highlight here also the main urban regions (especially Budapest), but we should additionally note that tweets - as well as Wikipedia articles - are referring to places, which are interesting and worth to talk about. By the way, the density is still higher in many areas where more intense presence of information society is assumed.

\section{Concluding remarks}

Our examples on the dimensions of information age inequalities confirmed that the topic is rather complex and has many facets to be discovered, although the composite picture of inequalities reflected that urban-rural and center-periphery disparities are common features of the spatial structure in every dimension of inequalities in Hungary. Nowadays, both accessibility, user and non-user, as well as usage quality disparities are existing, which all should be taken into account in regional information society analysis. To draw a composite picture we should combine both social and economic components from the unequal distribution of infrastructural conditions to the soft motives of cyberspace activities. By the aggregation of the different types of inequalities it would be possible to join the external (physical) and internal (social) side of the geography of the information society.

Acknowledgement: The research was supported by the Institute of Advanced Studies Kőszeg 


\section{BIBLIOGRAPHY}

Bennett, M. K. (1954) The World's Food. New York, USA: Harper and Row.

Budai, B. B.\& Tózsa, I (2007). E-közigazgatás [E-public administration] Debreceni Egyetem Agrár- és Müszaki Tudományok Centruma, Debrecen.

Cairncross, F. (1997) The death of distance. How the communication revolution will change our lives. Harvard Business School Press, Boston, USA.

Castells, M. (1996) The Rise of the Network Society. The Information Age: economy, society and culture. Oxford, UK: Blackwell Publishers.

Castells, M. (1997) The Power of Identity. The Information Age: economy, society and culture. Oxford, UK: Blackwell Publishers.

Castells, M. (1998) The Informational City - Information Technology, Economic Restructuring and the Urban-regional Process. Oxford: Basil Blackwell.

Corrocher, N., \& Ordanini, A. (2002) Measuring the digital divide: a framework for the analysis of cross-country differences. Journal of Information Technology: 17 (1): 9-19.

Dolničar, V. (2008) Application of an integral methodological approach to measuring the dynamics of the basic digital divide. Observatorio Journal: 4: 065-093

Eurostat (2013) Glossary:Community survey on ICT usage in households and by individuals. http://ec.europa.eu/eurostat/statistics-explained/index.php/

Glossary:Community_survey_on_ICT_usage_in_households_and_by_individuals

Fichman, R.G. (1992) Information Technology Diffusion: A Review of Empirical Research. Proceedings of the Thirteenth International Conference on Information Systems. Dallas, 195-206.

Fischer, E. (2013) Locals and Tourists map. Eric Fischer, Gnip, MapBox project. http:// mapbox.com/labs/twitter-gnip/locals

Freeman, L. C. (1979) Centrality in social networks. Conceptual clarification. Social Networks 1. 215-239.

Galácz, A., \& Molnár S. (2003) A magyarországi információs egyenlőtlenségek. [Hungarian information inequalities]. In: Dessewffy, T., \& Z. Karvalics, L. (Ed.), Internet.hu - A magyar társadalom digitális gyorsfényképe (pp. 138-159). Budapest: Aula Kiadó.

Goddard, J., \& Gillespie, A., \& Robinson, J., \& Thwaites, A. (1985) The impact of new information technology on urban and regional structure in Europe. In: Thwaites, A., \& Oakey, R. (Ed.), The Regional Economic Impact of Technological Change (pp. 215-242). London: Frances Pinter.

Graham, M., \& Zook, M. (2011) Visualizing Global Cyberscapes: Mapping User Generated Placemarks. Journal of Urban Technology: 18 (1): 115-132.

Hüsing, T., \& Selhofer, H., \& Korte, W.B. (2001) Measuring the digital divide: A proposal for a new index. IST Conference, 3. Dec. 2001, Düsseldorf.

ITU (2012) Measuring the Information Society. Geneva: International Telecommunication Union. 
Masuda Y. (1988) The Information Society as a Postindustrialised Society (Az Információs Társadalom mint Posztindusztriális Társadalom). Budapest: OMIKK.

Nagy, G. (2002) Területi különbségek az információs korszak küszöbén. [Regional differences at the threshold of the information age] Területi Statisztika: 42 (1): 3-25.

Norris, P. (2001) Digital Divide: Civic Engagement, Information Poverty, and the Internet Worldwide. Cambridge, UK: Cambridge University Press.

Odendaal, N. (2003) Information and communication technology and local governance: understanding the difference between cities in developed and emerging economies. Computers, Environment and Urban Systems: 27 (6): 585-607.

OECD (2001) Understanding the Digital Divide. Paris: OECD Publications.

Porat, M. U. (1977) The information economy. Definition and measurement. Washington D.C.: US Department of Commerce, Office of Telecommunications.

Servon, L. J. (2002) Bridging the Digital Divide: Technology, Community, and Public Policy. Oxford, UK: Wiley-Blackwell.

Storper, M., \& Venables A. J. (2003) Buzz: Face-To-Face Contact and the Urban Economy. Centre for Economic Performance, London School of Economics and Political Science, London, UK.

Trujillo, M.F. (2001) Diffusion of ICT Innovations for Sustainable Human Development.

www.payson.tulane.edu/research.

Umesao, T. (1963) Joho sangyo ron [On Information Industries]. Hoso Asahi: (jan): 4-17.

van Dijk, J. (2005) The Deepening Divide: Inequality in the Information Society. Thousand. Oaks, London, New Delhi: Sage Publications.

Wasserman, S., \& Faust, K. (1994): Social Network Analysis. Methods and Implications. Cambridge, UK: Cambridge University Press.

\section{ABSTRACTS}

By today it seems obvious that the use of information and communication technologies is inseparable from many spheres of everyday life. Also increasing number of practical experiences confirm that the information society and the information economy have perceptible influence on socio-economic inequalities, which have necessarily geographical projections as well. Although it is difficult to grab all the motives of geography-related inequalities of the information age, our study still attempts to collect some major dimensions of disparities. The paper aims to present the composite character of Hungarian information society differences in a regional context by applying conceptual and experimental approaches. First, the accessibility dimension of information age disparities is detailed by the application of typical statistical indicators. Secondly, we attempt to draw the picture of e-government disparities, a new layer of information inequalities, to represent differences between users and non-users. Next, we present examples on network-based inequalities as an experimental study on the importance of connectivity in the information economy. And finally, we give examples on novel forms of cyberspace inequalities reflecting regional differences of how people are using and taking advantage of information age possibilities. According to our results it was found that although the different dimensions of disparities reflected other motives of information age inequalities in Hungary, the urban-rural and center-periphery disparities happened to be common features of the spatial structure. 
Em nossos dias, parece óbvio que o uso das tecnologias de informação e de comunicação é inseparável de várias esferas da vida cotidiana. Um número crescente de experiências práticas também confirma que a sociedade e a economia da informação têm perceptível influência sobre as desigualdades sócio-econômicas - as quais, necessariamente, admitem reflexos geográficos. Embora seja difícil apreender todas as razões das desigualdades relacionadas à geografia na Era da Informação, nosso estudo tenta reunir algumas de suas principais dimensões no contexto regional húngaro à luz de abordagens conceituais e experimentais. Inicialmente, detalhamos a questão do acesso por meio da aplicação de indicadores estatísticos típicos para, em segundo lugar, esboçar um quadro das disparidades da governança eletrônica - uma nova camada das desigualdades informacionais - capaz de representar diferenças entre usuários e não-usuários. $\mathrm{Na}$ sequência, apresentamos exemplos de desigualdades baseadas na rede como um estudo experimental sobre a importância da conectividade para, por fim, exemplificarmos as novas formas de desigualdades no ciberespaço refletindo diferenças regionais sobre como as pessoas usam e tiram vantagem das possibilidades da Era da Informação. Nossos resultados nos indicam que embora as diferentes camadas das desigualdades reflitam outras razões das disparidades na Era da Informação na Hungria, as desigualdades urbano-rural e centro-periferia são feições comuns à estrutura espacial.

De nos jours, il n'y a pas aucun doute que l'usage des technologies de l'information et de la communication est inséparable de plusiers domaines de la vie quotidienne. Un nombre croissant d'expériences pratiques confirment que la société et l'économie de l'information sont capables d'influencer les inégalités sócio-économiques, y compris leurs éléments géographiques. En dépit des difficultés de trouver toutes les raisons des inégalités géographiques à l'Age de l'Information, on va les chercher dans le contexte régional hongrois à partir des approches conceptuelles et expérimentales. Pour cela, on utilise des estatistiques d'accèss à l'internet et, ensuite, on esquisse un cadre des disparités de la gouvernementalité éléctronique capable de représenter les différences entre usagers et non-usagers. On présente aussi quelques exemples d'inégalités numériques pour montrer l'importance de la conectivité et, finalement, on discute les rapports entre inegalités numériques et inegalités régionales (en considérant aussi les millieux urbainrural et centre-périphérie) pour réflechir comment les gens profitent des possibilités ouvertes par l'Age de l'Information.

En nuestros días, parece obvio que el uso de las tecnologías de información y de comunicación es inseparable de varias esferas de la vida cotidiana. Un número creciente de experiencias prácticas también confirma que la sociedad y la economía de la información tienen perceptible influencia sobre las desigualdades socioeconómicas - las cuales, necesariamente, admite reflejos geográficos. Aunque es difícil comprender todas las razones de las desigualdades relacionadas con la geografía en la Era de la información, nuestro estudio intenta reunir algunas de sus principales dimensiones en el contexto regional húngaro a la luz de enfoques conceptuales y experimentales. Inicialmente, detallamos la cuestión del acceso a través de la aplicación de indicadores estadísticos típicos para, en segundo lugar, esbozar un cuadro de las disparidades de la gobernanza electrónica - una nueva capa de las desigualdades informacionales - capaz de representar diferencias entre usuarios y no usuarios. En la secuencia, presentamos ejemplos de desigualdades basadas en la red como un estudio experimental sobre la importancia de la conectividad para, por fin, ejemplificar las nuevas formas de desigualdades en el ciberespacio reflejando diferencias regionales sobre cómo la gente usa y aprovecha las posibilidades de la Era de la Información. Nuestros resultados nos indican que, aunque las diferentes capas de desigualdades reflejan otras razones de las disparidades en la Ea de la información en Hungría, las desigualdades urbano-rural y centro-periferia son características comunes a la estructura espacial. 
INDEX

Mots-clés: société de l'information, inégalités régionales, gouvernementalité éléctronique, cyberespace, Hongrie

Palabras claves: sociedad de la información, desigualdades regionales, gobernanza electrónica, ciberespacio, Hungría

Keywords: information society, regional inequalities, e-government, cyberspace, Hungary

Palavras-chave: sociedade da informação, desigualdades regionais, governança eletrônica, ciberespaço, Hungria

\section{AUTHORS}

\section{ÁKOS JAKOBI}

Eötvös Loránd University (ELTE), Department of Regional Science \& Institute of Advanced Studies Kőszeg (IASK). Email: jakobi@caesar.elte.hu

\section{BRIGITTA ZSOM}

TOPdesk Hungary. Email: zsom.brigi@gmail.com

\section{ZSÓFIA VIDA}

Hungarian Academy of Sciences (MTA), Library and Information Centre, Department of Science Policy \& Scientometrics. Email: vida.zsofia@konyvtar.mta.hu 